\title{
Growth ring analysis of fossil coniferous woods from early cretaceous of Araripe Basin (Brazil)
}

\author{
ETIENE F. PIRES ${ }^{1}$ and MARGOT GUERRA-SOMMER ${ }^{2 *}$ \\ ${ }^{1}$ Universidade Federal do Tocantins, Campus de Porto Nacional, Colegiado de Ciências Biológicas \\ Rua 07, Quadra 12, s/n, Bairro Jardim dos Ipês, 77500-000 Porto Nacional, TO, Brasil \\ ${ }^{2}$ Universidade Federal do Rio Grande do Sul, Departamento de Paleontologia e Estratigrafia, Instituto de Geociências \\ Campus do Vale, Av. Bento Gonçalves, 9500, Bairro Agronomia, 91540-000 Porto Alegre, RS, Brasil \\ Manuscript received on October 13, 2009; accepted for publication on October 6, 2010
}

\begin{abstract}
Growth ring analysis on silicified coniferous woods from the Missão Velha Formation (Araripe Basin - Brazil) has yielded important information about periodicity of wood production during the Early Cretaceous in the equatorial belt. Despite warm temperatures, dendrological data indicate that the climate was characterized by cyclical alternation of dry and rainy periods influenced by cyclical precipitations, typical of tropical wet and dry or savanna climate. The abundance of false growth rings can be attributed to both occasional droughts and arthropod damage. The present climate data agree with palaeoclimatic models that inferred summer-wet biomes for the Late Jurassic/Early Cretaceous boundary in the southern equatorial belt.
\end{abstract}

Key words: Araripe Basin - Brazil, dendroclimatology, pre-rift phase, fossil woods.

\section{INTRODUCTION}

The term equable (warm, low seasonality) is often used to describe Jurassic and Cretaceous climate, when there was only a sluggish equator to pole atmosphere and ocean circulation (Barron and Washington 1982). The need for its better definition of the term was indicated by Axelrod (1984) because recent modeling results show that it may be a simplistic view of that climate. The distribution and thermal tolerances of land plants during the evolution of a greenhouse phase provide one of the main sources of climatic evidence through the Late Jurassic and Early Cetaceous. A climate uniformly warm was inferred by the presence of fossil flora in low and high latitudes according to their composition (ferns, cycadophytes and conifers) and latitudinal spread (Jefferson 1982). However, palaeoclimatic reinterpretations (Drinnan and Chambers 1986) concluded that southern and

Correspondence to: Etiene Fabbrin Pires

E-mail: etienefabbrin@uft.edu.br

${ }^{*} \mathrm{CNPq}$ northern floras may represent warm summer climates rather than an year-round warmth. Frakes et al. (1992), based on the development of evaporites, concluded that the latest Jurassic appears to have been arid, at least in low and middle latitudes. However, the Early Cretaceous was much more humid and coal deposits became prominent in the equatorial region (Peru and Mexico) (Ziegler et al. 2003).

Palaeoclimate zones based on the global distribution of lithological climate indicators, such as coals, evaporites and aeolian sands, as well as the distribution of climate sensitive plants and animals, were defined by different authors. Ziegler (1990) applied the biome scheme developed by Walter (1985) that reduced the macroclimate of present day surface to nine major biomes, for palaeoclimatic global reconstruction.

The most recent palaeoclimatic maps for the Phanerozoic are presented by Scotese (2003) that plotted on palaeogeographic maps the distributions of sensitive 
climate rocks, plants and animals that form specific climatic belts. However, these time intervals maps are too huge for studies on specific time stages.

Based on a compilation of geological and palaeontological data, Chumakov (1995) proposed world climatic maps for the Cretaceous by identifying eight climatic belts pole to pole. During the Early Cretaceous (Berriasian), the equatorial region of the South AmericaAfrica landmass included in the Tropical-Equatorial hot arid belt was considered to have been arid without evidence of sufficient moisture to have supported forests.

Creber and Chaloner (1984) ratified previous global palaeoclimatic reconstruction indicating a very broad equatorial zone $\left(32^{\circ} \mathrm{N}\right.$ to $\left.32^{\circ} \mathrm{S}\right)$ at the Cretaceous, as evidenced by the absence of growth rings in woods or very weakly defined ones. Consequently, at Cretaceous times, the lower latitudes would generally experience a non-seasonal climate, which permitted more or less continuous tree growth as a result of photoperiodic mechanism coupled to an annual leaf-flushing period.

In the northeastern Brazilian interior basins (Araripe, Rio do Peixe, Recôncavo/Tucano/Jatobá, and Iguatu), the sedimentary records of the pre-rift sequence occur in scattered exposures (Fig. 1a, b). They represent the remains of what was once a great shallow basin, the Afro-Brazilian Depression - ABD (Ponte 1972).

Climatic differences invoked by Da Rosa and Garcia (2000) that have divided the ABD into two regions was supported by palaeocurrent, provenance, diagenetic, and palaeontological data. The abundance of silicified woods in the Missão Velha Formation of Araripe Basin suggested the development of a Berriasian conifer forest on the humid northern highland margins, which was separated from the arid to semi-arid conditions that prevailed in the southern part of the basin. These conditions were evidenced by the presence of extensive aeolian facies.

The present study outlines analyses of a silicified wood assemblage from an outcrop of the Missão Velha Formation of Araripe Basin about more or less $8^{\circ} \mathrm{S}$. The main focus of this paper is: 1) to document dendroclimatic analysis of growth rings using statistical procedures; 2) to offer palaeoclimatic inferences based on growth ring analyses; 3 ) to refine global palaeoclimatic models inferred for the Late Jurassic/Early Cretaceous, and also the regional climates inferred by the AfroBrazilian Depression at that time interval.

\section{GEOLOGICAL SETTING}

The Araripe Basin is the most extensive of the Brazilian Northeastern Interior basins, with an area of approximately $12.200 \mathrm{~km}^{2}$ located on the boundary of Ceará, Pernambuco and Piauí states $\left(7^{\circ} 02^{\prime}-7^{\circ} 49^{\prime} \mathrm{S}\right.$ and $38^{\circ} 30^{\prime}$ $40^{\circ} 55^{\prime} \mathrm{W}$ ) (Fig. 1c).

The stratigraphic chart proposed by Assine (1992) characterized the Araripe Basin as a relictual composite of four genetically distinct basins, partially superimposed in space, and represented by four stratigraphic sequences bounded by unconformities. The unfossiliferous Paleozoic Sequence, corresponding to the Cariri Formation, was dated as Siluro-Devonian based on supposed lithological affinity with rocks of the TucanoJatobá and Parnaíba basins; the Juro-Neocomian Sequence is composed by the basal siltstone and shalerich Brejo Santo Formation, which is overlain by the Missão Velha Formation. This Formation is redefined in relation to prior studies (Beurlen 1962, Braun 1966) to contain medium to coarse-grained sandstones with silicified woods superposed by the gray shales of the Indaiara Formation. The Aptian-Albian Sequence included the Barbalha and Santana Formations, and the Albian-Cenomanian Sequence is formed by the unfossiliferous Exu Formation.

The Missão Velha alluvial system also encompasses the Antenor Navarro Formation in the Rio do Peixe Basin, the Sergi Formation in the Reconcavo Tucano-Jatobá Basin, and has been correlated to the N'Dombo Formation (Gabon Basin), Lucula Formation (Congo-Cabinda Basin) and Offshore Congo, all African basins (Da Rosa and Garcia 2000). The age of the Missão Velha Formation was estimated as Late Jurassic based upon ostracods assemblages (Pinto and Sanguinetti 1958a, b) and no older than Early Cretaceous (Berriasian) by Horne (1995) which corresponds to the São João Chronostratigraphic Stage of the Araripe Basin (Coimbra et al. 2002).

The stratigraphic chart of Araripe Basin (Arai et al. 2004) (Fig. 2), and also the stratigraphic revision of the Lower Cretaceous Brazilian northeastern interior basins defined by Arai (2006) indicates that the Dom 


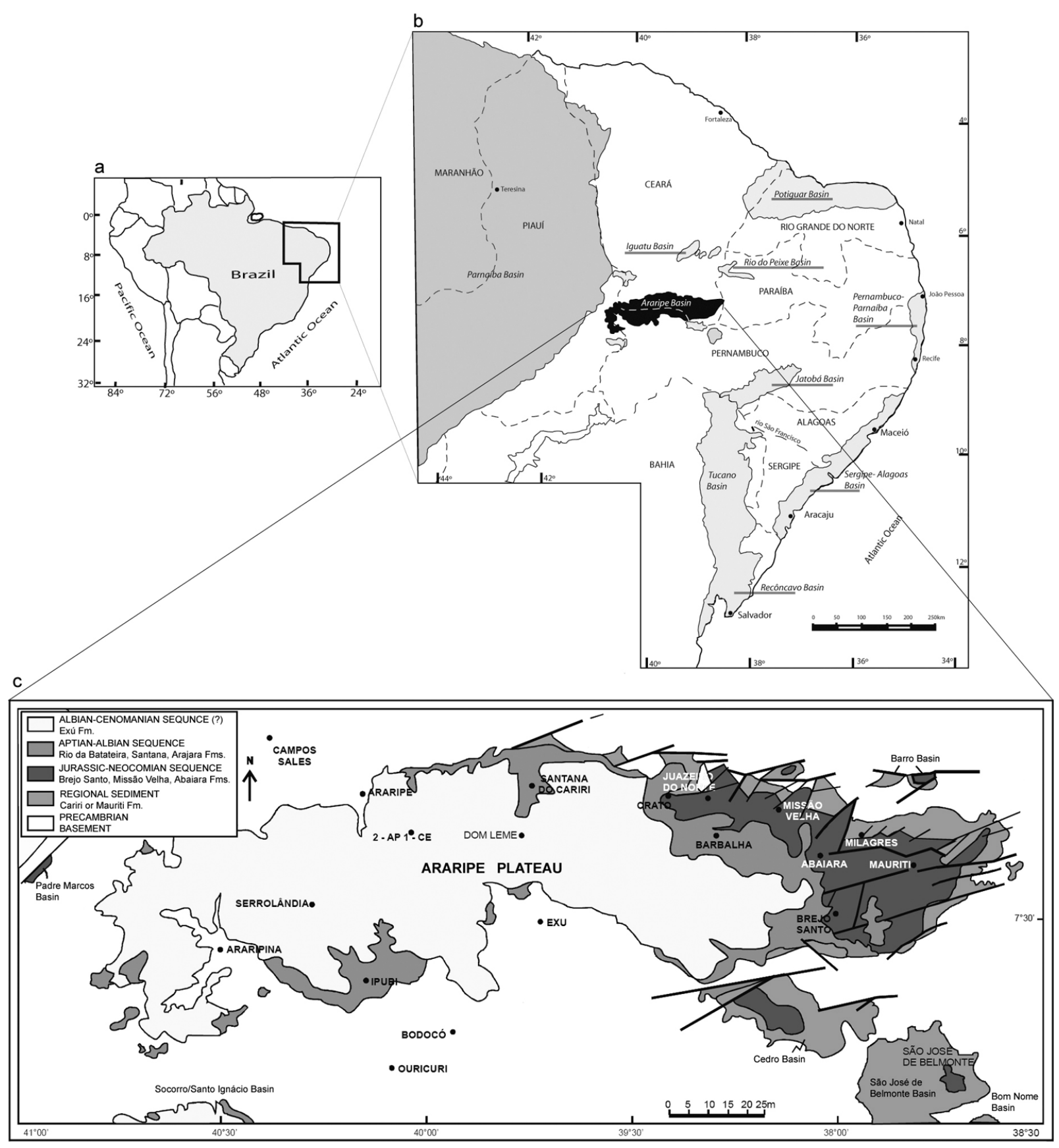

Fig. 1 - Location of the studied area; a) map of Brazil; b) map of northeastern Brazil showing the location of Araripe Basin (in black) and the interior basins of the northeast of Brazil; c) geographic delimitation of Araripe Basin.

João Stage is mostly within the Jurassic, although its uppermost part can range into the basal Cretaceous (Berriasian). On the other hand, it was concluded that the term "Missão Velha Formation" was inadequately related to two distinct stratigraphic units that correspond to the Dom João Stage (Missão Velha Formation sensu stricto), with a Berriasian maximum age interval, and another one to the Alagoas Stage (current Rio da Batateira Formation). In the present study, the designation "Missão Velha Formation" is used to identify a lithostratigraphic pre-rift unit of the Araripe Basin, according the framework of Arai et al. (2004). 


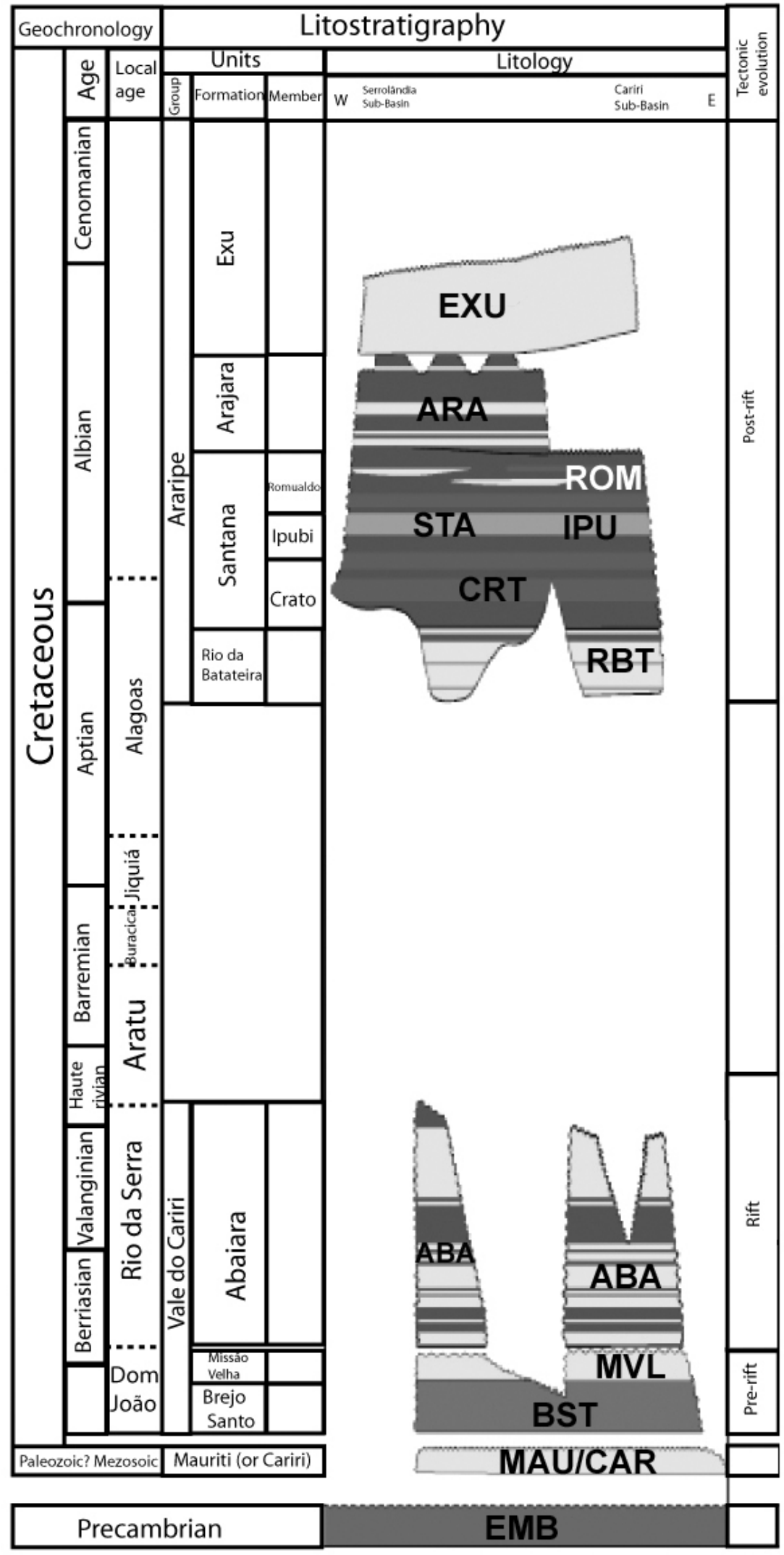

Fig. 2 - Stratigraphic column of the Araripe Basin (modified from Arai et al. 2004). 
The wood-bearing Grota Funda (UTM: 24M 0489727/9196725) lies $6 \mathrm{~km}$ east of Missão Velha city, bordering route 293 in Ceará State. The exposed sedimentary sequence is $4 \mathrm{~m}$ high and $30 \mathrm{~m}$ wide. This site exposes a prominent fluvial and aeolian facies, composed of a succession of medium-coarse sandstones with trough cross-bedding, interbedded with beds of trough cross-bedded conglomerates. Silicified woods are the exclusive fossils and occur in the coarse-grained sandstone or rolled, rarely as components of the conglomerates. The fossil woods show no preferential orientation.

\section{DENDROCLIMATOLOGIC ANALYSIS}

\section{WOOD DESCRIPTION}

The fossil fragments of the wood-bearing Grota Funda have a diameter of 0.1-1 m. The fragments are not rounded or abraded, and bark is also present in rare specimens, suggesting that they have not been transported far from their source. Forty-five samples were collected from the site, and fifteen mature woods were selected for detailed palaeoclimatological growth ring analysis.

Large dispersed fossil woods (Fig. 3a, b) with uncompressed diameters of $0.50-1 \mathrm{~m}$ and lengths weathered out up to $3 \mathrm{~m}$ are also common in the sandstones or at the ground surface. This character is indicative of hypo-autochthonous depositional conditions. The smaller wood fragments were probably produced by desegregation of bigger trunks. Thin-sections from pieces of the external secondary xylem of these specimens were also studied. The results showed that the large and small woods were anatomically equivalent.

The wood is mostly silicified and light brow. Growth rings are prominent in transverse section; earlywood and latewood are clearly distinguishable (Fig. $3 c)$. Boring activities are evident in the outer surface of several samples (Fig. 3b, c). Detailed analysis of the boring system, reported by Pires and Guerra-Sommer (2009), provides the first relevant data for addressing evidences of phytophagy in these coniferous silicified woods. The damage pattern was linked to order Isoptera, known from the Early Cretaceous by wing impressions of the species Valditermes brenanae (family Mastotermitidae) found in Weald Clay by Jarzembowsky (1990). Consequently, the evidences of plant-arthopod interac- tion in the wood assemblage of the Missão Velha Formation constrained the depositional interval to the Early Cretaceous.

Formal taxonomic analyses were not developed in the studied wood assemblage. Nevertheless, two gymnosperm xylotypes, which is a term defined by Wheeler and Lehman (2005), were recognized based on parameters such as the size of earlywood tracheids in transverse section, patterns of radial pitting on tracheids and cross field pitting in radial section. The woods possess resiniferous tracheids scattered within growth rings. The anatomical details allowed the differentiation between two wood types: 1. Cupressoid/Podocarpoid wood type $1 ; 2$. Araucarioid wood type 2. Main features of these wood types are detailed in Figure 4.

\section{ANALYSIS OF GROWTH RINGS}

Growth rings were measured from transversely polished sectioned blocks of the silicified wood using a binocular stereoscopic microscopy or a paquimeter directly on the polished wood surface. Details of growth ring structure were obtained by the observation of thin sections on transmitted light optical microscopy.

Statistical procedures used in the analyses of growth rings from fifteen fragments of fossil wood, followed those proposed by Fritts (1976: based on Douglass 1928), Creber, (1977), Creber and Chaloner (1984), and Parrish and Spicer (1988). They include the variance of ring width, Mean Sensitivity (MS), Annual Sensitivity (SA), and growth ring classification scheme.

Inter annual variation in growth rate is determined by Mean Sensitivity indicators, which represent a measurement of the sensitivity of trees to variation in their environment. The values of mean sensitivity range from 0 to a maximum of 2. An arbitrary value of 0.3 is taken to separate "complacent" trees that grow under a favorable and uniform climate $(\mathrm{MS} \leq 0.3)$ from those that are "sensitive" to fluctuating climate parameters (MS $\geq 0.3$; Douglas 1928). Different authors (Creber and Chaloner 1984, Francis 1984, Brea 1998, Francis and Poole 2002, Pires et al. 2005) have used mean sensitivity as a tool for palaeoclimatic analysis. According to Keller and Hendrix (1997), Mean Sensitivity values are not necessary a reliable measure of environmental factors. Kay (1978) also considered that a tree of a single 


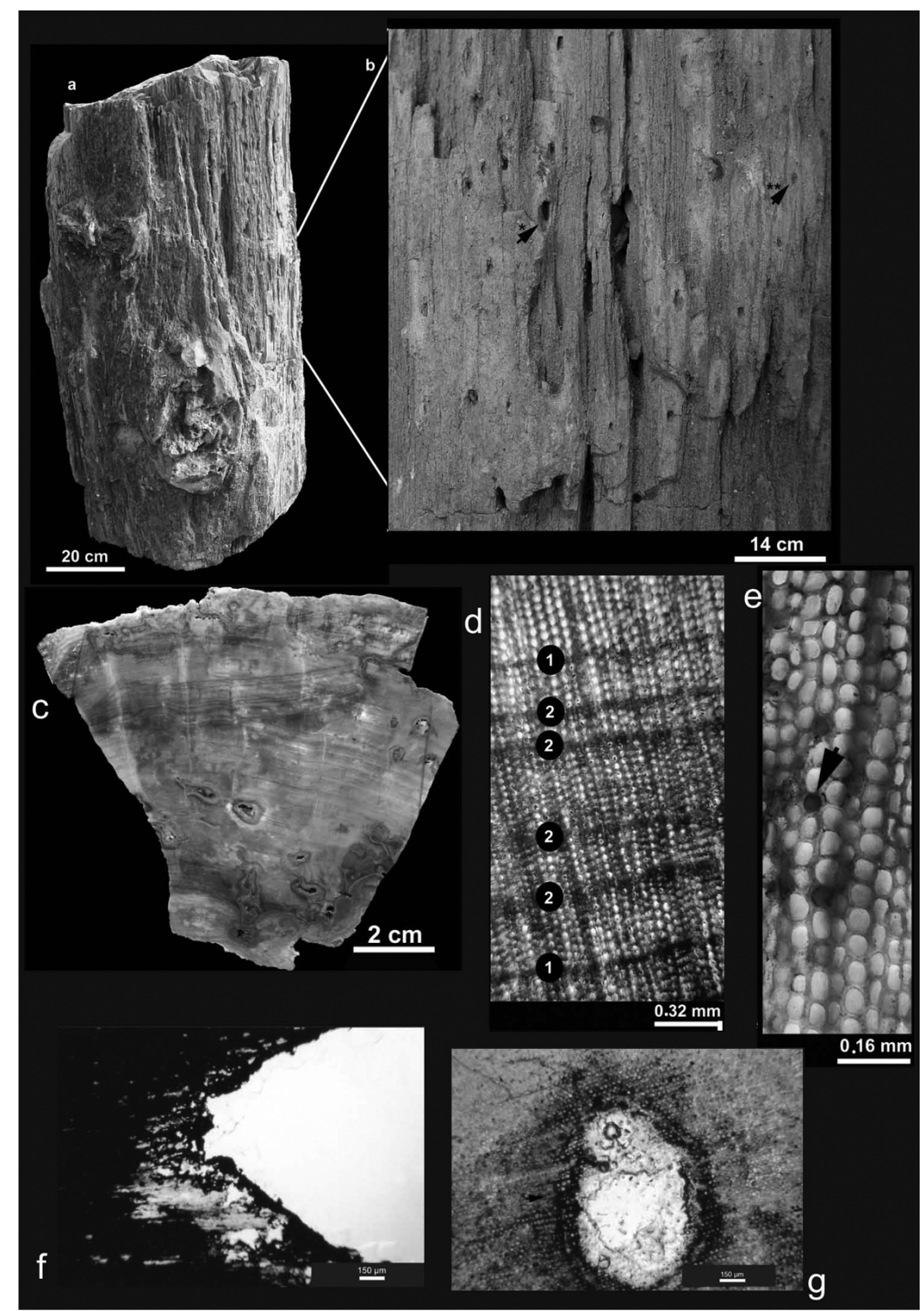

Fig. 3 - a) large fossil wood from the Grota Funda outcrop; b) detail of the outer surface showing the smallest eliptical features $\left(^{*}\right)$ corresponding to invertebrate bores and large holes $(* *)$, irregular in shape, corresponding to regions of collapsed walls of internal borings; c) cross section of large permineralized wood showing growth ring boundaries and circular to irregular diameter of axial tunnels, following the curvature of growth rings; d, e) transverse thin sections of fossil woods (optical microscope); d) demonstrating a limit of a true growth ring (arrow 1) and a lot false growth rings (arrow 2); e) detailing a resiniferous tracheid; f) radial section; g) transverse section, showing the necrotic tissue.

species growing within the interior of a forest naturally has lower sensitivity values than those growing along the forest borders, regardless of climatic variability.

The degree of year to year variability is demonstrated by Annual Sensitivity, which is derived from the equation of Mean Sensitivity and corresponds to the difference in width between a pair of consecutive rings divided by their average width. The indicator may be a more valid measure of the environmental variability to which the tree has been exposed (Keller and Hendrix 1997).

The analysis of the general growth ring characterization in the early and latewood was based on the cell amount and diameter, cellular walls thickness, as well the nature of earlywood/latewood transition, according to IAWA Committee (1989). 


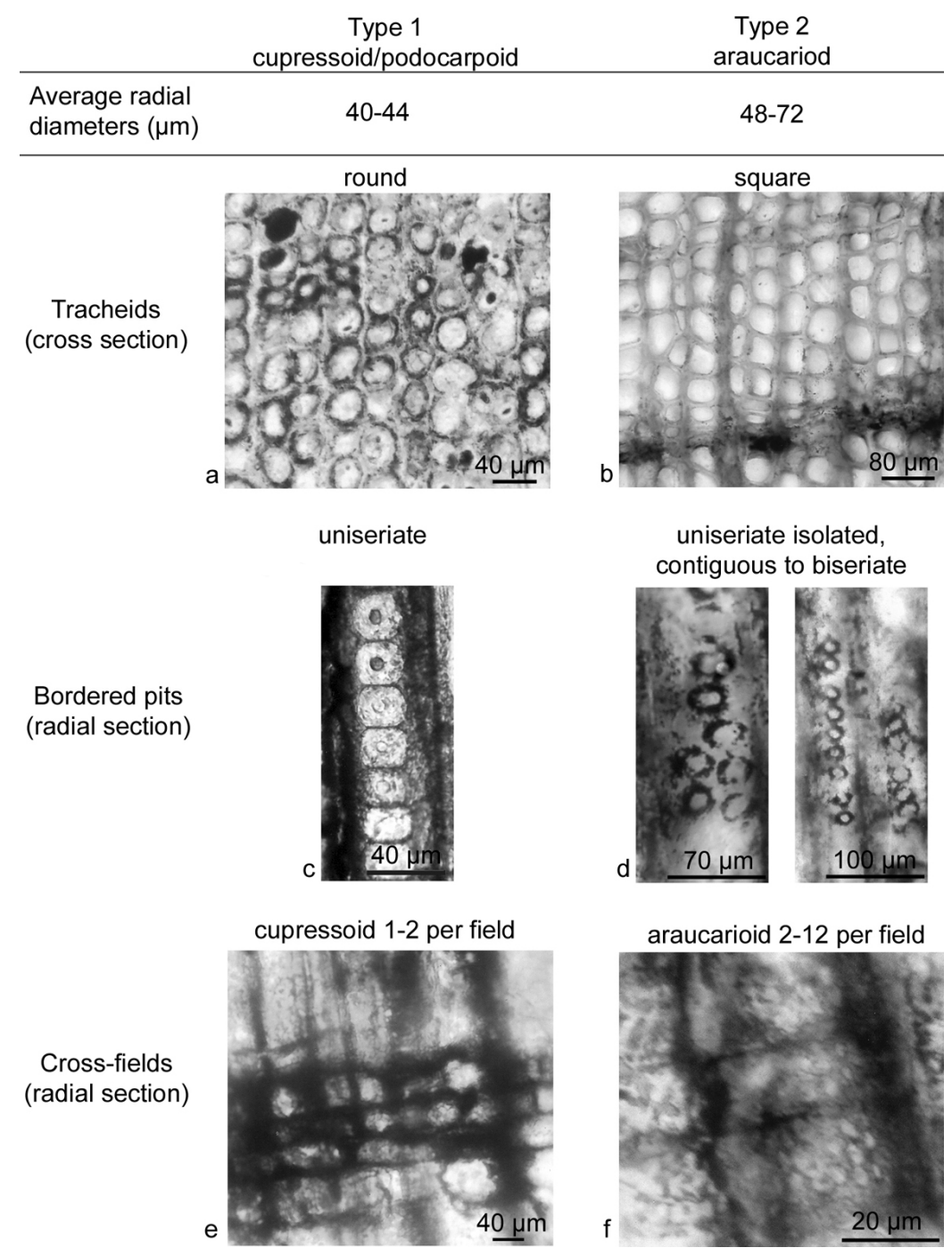

Fig. 4 - Diagnostic anatomical patterns found in xylotypes 1 and 2 from Grota Funda outcrop.

The nature of seasonality can be also inferred by the proportion of earlywood/latewood (Parrish and Spicer 1988). Thus, distinct patterns of latewood in temperate modern woods, which reflect growing conditions, can be applied in fossil assemblages providing information about seasonality (Spicer and Parrish 1990).

Mean ring width is used to indicate the growth rate and length of growing season. According to Fritts (1976), the wider the ring, the faster the growth or the longer the growing season.

The classification scheme of growth rings proposed by Creber and Chaloner (1984) carried out a study on the influence of environmental factors on woody struc- ture based on relationships of earlywood/latewood, which determines the boundary by the cumulative sum deviation from the mean (CSDM) radial cell across a single growth ring. Six types of growth patterns were identified, all of them related to distinct environmental conditions: A, B, C, D, E and O. In the present study, two samples were selected, one of each recognized wood type to test the classification proposed by Creber and Chaloner (1984).

The specimens are stored in the Laboratory of Paleobotany, Departamento de Estratigrafia e Paleontologia, Instituto de Geociências, Universidade Federal do Rio Grande do Sul, Porto Alegre, Rio Grande do Sul, 
Brazil, and in the Collection of Paleovertebrates, Paleoinvertebrates and Paleobotany, Departamento de Geologia of Instituto de Geociências, Universidade Federal do Rio de Janeiro, Rio de Janeiro, Brazil.

\section{RESULTS}

Statistical data were obtained from 277 rings in 15 samples. The Mean Sensitivity is $0.191-0.902$; the average of Mean Sensitivity is 0.427 ; the minimum annual sensitivity is 0 , and the maximum annual sensitivity is 1.147 (Table I).

The maximum annual sensitivity exceeds 0.7 in almost all samples, except in PB 3854. The annual sensitivity of the specimens increases year after year, except in 2 specimens (PB 371, PB 3854) that have low mean sensitivity (Fig. 5a, b).

All the specimens have wider growth rings according to IAWA Committee (1989). The measured growth rings, range from 0.54-7.38 mm wide (mean: $2.19 \mathrm{~mm}$ ). Within individual growth rings the transition from earlywood to latewood is abrupt (Fig. 3d). Latewood is very narrow, consisting of 1-2 narrow cells with thick walls and narrow lumen (Fig. 3d), indicating that the cell conducting space is small. The earlywood is characterized by thin-walled cells with a wide lumen. A large proportion of earlywood (60-100 cells) and small quantities of latewood (1-2 cells) is common to all samples, but the ring boundaries are well defined.

The growth ring types of the studied assemblage are similar to type D (Fig. 5c) in the ring classification scheme of Creber and Chaloner (1984).

False growth rings are abundant in most samples (Fig. 3d). Their occurrence (more than 1 per growth ring) is linked to the final portion of the earlywood, at the end of the growing season. They may be distinguished from seasonal growth rings because they have a gradual transition to thick-walled narrow cells, then a gradual reversal to large thin-walled cells (Spicer 2003).

Resiniferous tracheids are scattered (Fig. 3e) in the xylem tissue. Wood damage is evidenced by the presence of galleries, bordered by a zone of reaction tissue, often consisting of a narrow dark outer band and a wide inner area, which is thought to be a necrotic tissue (Fig. 3f, g).

\section{PALEOCLIMATIC INTERPRETATIONS}

\section{RESUlTS DisCUSSION}

Statistical analyses of the wood assemblage from Grota Funda locality, of the Araripe Basin are important for inferring palaeoclimatic patterns. The Mean Sensitivity analysis indicates that individual samples corresponds mainly to sensitive types (87\%), with MS more than 0.3 . These data point to an irregular growth environment. On the other hand, the annual sensitivity above 0.7 which is present in almost all samples, indicates the occurrence of extreme climatic events. High variations in the growth ring width associated to a high annual sensitivity values indicate good conditions for tree growth, but with variable water supply year by year (Gérards et al. 2007).

The general characterization of the wider growth rings shows that growth was fast in a relatively short growing period, or that the growing period was large, or both. According to Spicer (2003), the small amount of latewood suggests that the transition from full growth to full dormancy was rapid and there was not a long period of growth slowdown.

Growth rings with a gradual transition from earlywood to latewood are encountered mainly in the middle latitudes of both hemispheres, where climatic models predict the occurrence of temperate climates. This "progressive type of wood" (types B, C and E of Creber and Chaloner 1984) is typical from Early Cretaceous woods in middle latitudes for both hemispheres.

The similarity of the studied material to type D, proposed by Creber and Chaloner (1984), indicates that the growing season was relatively uniform, with a terminal event representing a cessation or retardation of cambial cell division.

The presence of false growth rings reflects that external factors affected the different cycles of growth. These structures can be produced by: water supply restrictions, occurrence of fire or freezing, or invertebrate attack (Spicer 2003). Otherwise, more than a single false growth ring was observed within a single growth ring. Consequently, the origin of these anomalous growth rings could be related to plant stress represented by the occasional droughts at the end of growing season and arthropod-plant interaction. 

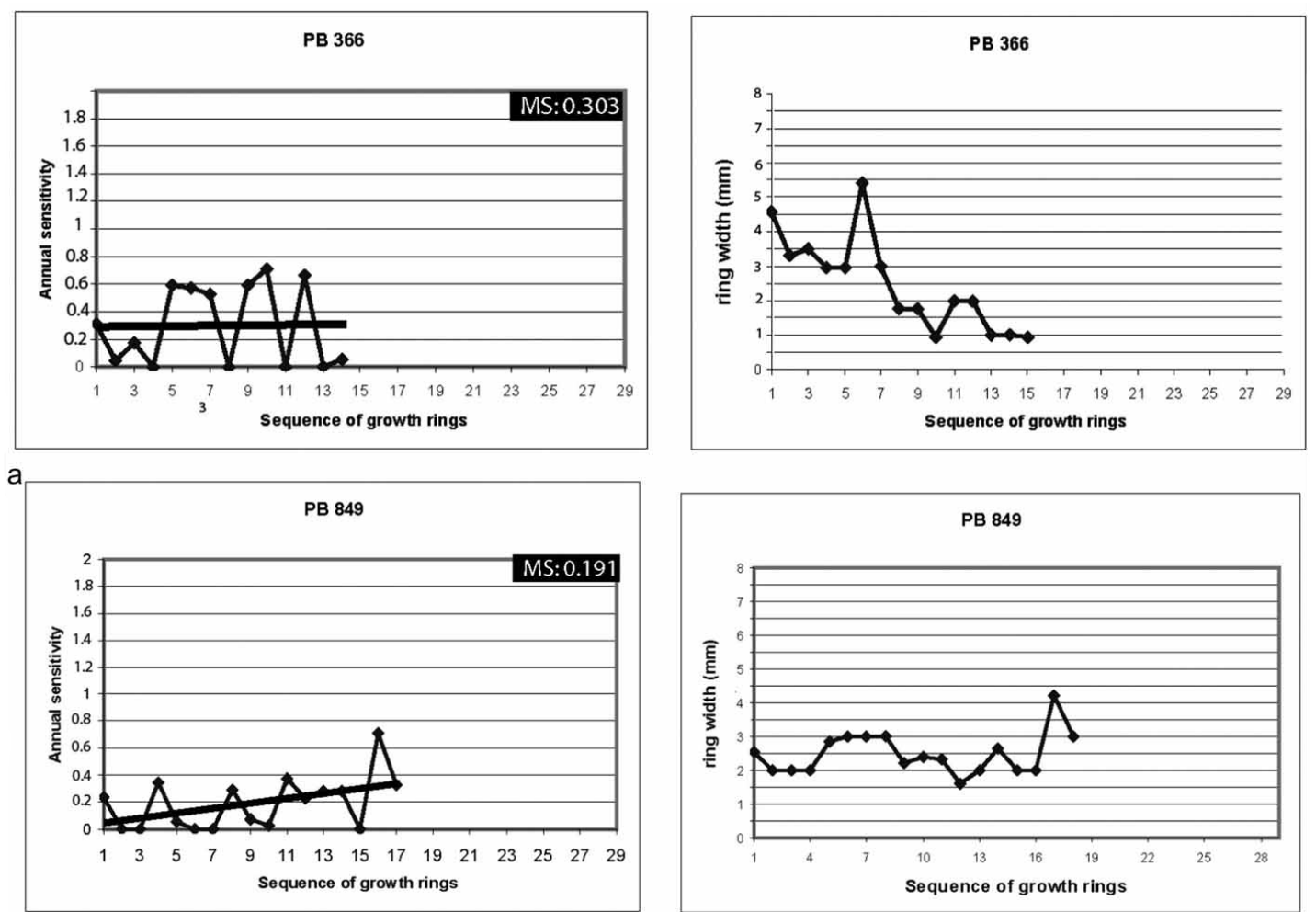

b
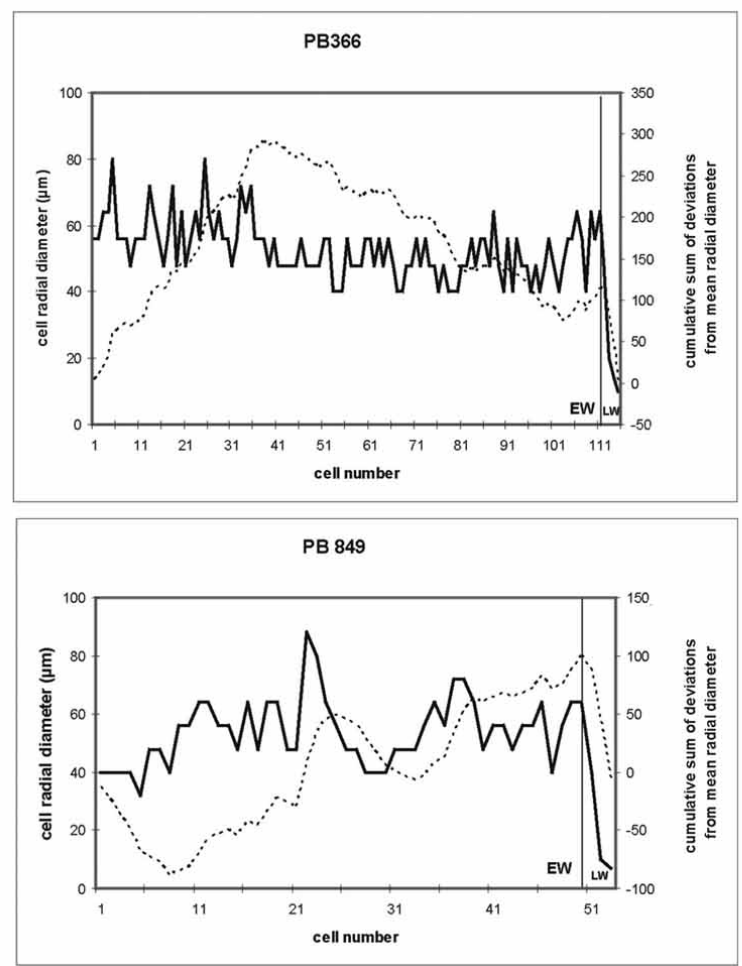

Fig. $5-\mathrm{a}, \mathrm{b}$ ) Annual sensitivity and ring width graphs of 2 samples of fossil woods; c) variation in cell radial diameter along selected growth rings (solid line) and cumulative sum of deviations from mean radial diameter (dashed line) in 2 samples - PB 366 and PB 849. Vertical line separates earlywood (EW) from latewood (LW). 
TABLE I

Results of growth rings analysis; complacent values in italics.

\begin{tabular}{c|c|c|c|c|c|c|c|c}
\hline & Samples & $\begin{array}{c}\text { Number } \\
\text { of growth } \\
\text { rings }\end{array}$ & $\begin{array}{c}\text { Minimum } \\
\text { ring width } \\
(\mathrm{mm})\end{array}$ & $\begin{array}{c}\text { Maximum } \\
\text { ring width } \\
(\mathrm{mm})\end{array}$ & $\begin{array}{c}\text { Mean } \\
\text { ring width } \\
(\mathrm{mm})\end{array}$ & $\begin{array}{c}\text { Mean } \\
\text { sensitivity } \\
\text { MS }\end{array}$ & $\begin{array}{c}\text { Minimum } \\
\text { annual } \\
\text { sensitivity }\end{array}$ & $\begin{array}{c}\text { Maximum } \\
\text { annual } \\
\text { sensitivity }\end{array}$ \\
\hline 1 & PB 93 & 23 & 1.25 & 6.55 & 2.38 & 0.381 & 0 & 0.936 \\
2 & PB 366 & 15 & 0.95 & 3.33 & 2.47 & 0.303 & 0 & 0.712 \\
3 & PB 367 & 20 & 0.70 & 3.57 & 1.78 & 0.525 & 0 & 1.307 \\
4 & PB 371 & 24 & 1.64 & 4.00 & 2.68 & 0.312 & 0 & 0.946 \\
5 & PB 675 & 23 & 0.55 & 4.86 & 2.13 & 0.474 & 0 & 1.286 \\
6 & PB 758 & 18 & 0.95 & 5.45 & 2.41 & 0.359 & 0 & 1.011 \\
7 & PB 791 & 7 & 1.55 & 6.25 & 3.09 & 0.902 & 0.268 & 1.226 \\
8 & PB 849 & 18 & 2.00 & 4.20 & 2.49 & 0.191 & 0 & 0.709 \\
9 & PB 900 & 8 & 1.89 & 7.38 & 3.57 & 0.587 & 0.189 & 1.147 \\
10 & PB 3826 & 22 & 0.86 & 3.86 & 1.82 & 0.334 & 0.038 & 0.943 \\
11 & PB 3828 & 29 & 0.76 & 3.62 & 1.47 & 0.407 & 0.033 & 0.971 \\
12 & PB 3836 & 20 & 0.54 & 3.57 & 1.61 & 0.546 & 0 & 1.125 \\
13 & PB 3840 & 8 & 1.15 & 2.53 & 1.96 & 0.365 & 0.111 & 0.750 \\
14 & PB 3854 & 17 & 0.97 & 3.35 & 1.55 & 0.262 & 0 & 0.660 \\
15 & PB 3860 & 25 & 0.69 & 2.78 & 1.43 & 0.466 & 0 & 1.045 \\
\hline Total/mean & 277 & & & 2.19 & 0.427 & & 0 \\
\hline
\end{tabular}

\section{Dendrological Analyses as a Climatic and PALEOCLIMATIC TOOL}

Many authors use dendrological analyses as a climatic and paleoclimatic tool. Growth rings in modern conifer woods were quantitatively analyzed to investigate the relationship between leaf longevity and the growth ring boundaries (Falcon-Lang 2000b). These data suggest that leaf longevity exerts an important control on growth ring markedness, in addition to the influence exerted by the growing environment (climatic and edaphic conditions). The significance of these results for the palaeoclimatic analysis of growth rings in fossil woods is discussed with reference to two case-studies: (1) the Early Carboniferous tropical climate of the British Isles and (2) the Early Cretaceous polar climate of the Antarctic Peninsula.

Falcon-Lang (2000a) proposed a method in which moderns coniferopsids woods produced by deciduous and evergreen trees may be distinguished from one another on the basis of a quantitative analysis of growth ring anatomy. The author used the CSDM, which has been used by Creber and Chaloner (1984). These data suggest that, in most cases, it may be possible to distinguish between evergreen and deciduous fossil coniferopsid species using wood anatomical characteristics.

Gérards et al. (2007), based on dendroclimatologic data, confirm that, during the Early Cretaceous (Berriasian), the Mons Basin (Belgium), located at $30-35^{\circ} \mathrm{N}$ in palaeogeographic models (Scotese 2003), presumably in a tropical climate, was characterized by a succession of marked dry and wet seasons under unstable palaeoenvironmental conditions. Otherwise, evidence of seasonal climate in the southern middle latitude was obtained in growth ring analyses by Jefferson (1982) in the Early Cretaceous (Alexander Island - Antarctic), which indicates moderate to high seasonality. Falcon-Lang and Cantrill (2000) also reported for the Alexander Island (Albian) similar wood patterns, from Araucarioxylon (invalid genus), Podocarpoxylon and Taxodioxylon morphotypes.

On the other hand, some authors suggest restrictions in the use of growth ring analysis as a palaeoclimatic tool. Brison et al. (2001), based on growth rings analyses from fossil woods of different Mesozoic locali- 
ties scattered on five continents, looked at the geographical and taxonomical distribution of the tree growth ring types defined by Creber and Chaloner (1984). The authors concluded that growth rings in Mesozoic woods were not determined by environmental factors alone, and were influenced by endogenous factors. Consequently, a palaeoclimatological analysis of the growth ring types would to be based on taxonomically diverse assemblages that can include applications at a more local scale, either geographic or temporal.

Likewise, based on processed data from the International Tree-Ring Data Bank, Falcon-Lang (2005) established a global climate analysis of growth rings in woods. Quantitative growth rings analysis of fossil woods may be used only in well-constrained palaeoecological studies, where taxonomic and climatic sources of variability can be controlled, and, additionally, as a qualitative tool in palaeoclimatic and palaeoecological analysis. Thus, the author does not recommend the use of quantitative percentage latewood data and mean ring width data as palaeoclimatic indicators.

Dendroclimatological studies demonstrate that the growth pattern of woods represents palaeoclimatic signatures of seasonal cycles. Any cyclical variation in growing conditions can bring about the growth ring origin, but most often the controlling factors of growth can be: 1) photoperiod, 2) temperature, and 3) water supply and precipitation. In the Tropical-Equatorial Hot arid belt (Chumakov 1995), where photoperiod and temperature do not significantly vary, cyclical periods of water restriction could be the limiting growth factor.

The unusual conditions that allows the generation of growth rings in plants close to the paleopoles and in those from the tropics in Early Cretaceous are generally interpreted in terms of a high carbon-dioxide greenhouse world (Chaloner and McElwain 1997).

Different geological data indicate that the conifer assemblage of the Missão Velha Formation was derived from low-lying areas, in adjacent floodplain (Da Rosa and Garcia 2000), at low latitudes $\left(8^{\circ} \mathrm{S}\right)$, during the climax of a greenhouse phase (Fischer 1984, Frakes et al. 1992), with increasing atmospheric $\mathrm{CO}_{2}$ (Tajika 1999).

The similarities among the statistical data obtained from two different wood types could suggest alternatively that:
1) the features of the growth rings, in this case, were environmentally induced and not a consequence of the growth characteristics of a particular species that could have been genetically coded;

2) increased stress conditions could act as an artifact in mean sensitivity data;

3) taxonomic affinities among xylotypes would produce similar growth ring pattern.

\section{Paleoclimate And Biome}

As it is indicated by palaeoclimatic models (Chumakov 1995, Scotese 2003), a boreal climate must be discarded for the Missão Velha Formation. The Köppen climate classification (Köppen 1936) is one of the most widely used modern climate classification systems. It is based on the floristic and ecological patterns of each region of Earth, establishing boundaries between climatic regions that reflect the areas of prevalence of each type of vegetation, considering the seasonality, temperature, and precipitation. According to Köppen (1936) two different types of climates occur in tropical region: 1) the Tropical/megathermal climates and 2) Dry (arid and semiarid) climates. In the broader tropical climate, three different climate types are included: 1. Tropical rainforest climate; 2. Tropical monsoon climate; and 3. Tropical wet and dry or savanna climate.

As it is demonstrated by the presence of growth rings in the fossil woods here analyzed, the Tropical rainforest climate must be discarded for the deposition of the Missão Velha Formation because trees that grow under a non-seasonal climate, as in the tropics, generally show more or less uniform secondary wood (Valdes and Sellwood 1993).

Global palaeogeography dominated by the large, middle latitude, Equator-parallel Brazilian-African landmass, would have been particularly conducive for monsoon circulation. The monsoon system is a dynamic component of the modern climate system. The inherent seasonality of monsoon circulation results in cool, dry winters and warm, wet summers over the continents. Monsoon circulations are driven by different rates of response to the land and the oceans, and to solar heating in summer and heat loss radiation in winter. The large seasonal swings in land temperature and small sea- 
sonal changes in ocean temperature reflect these contrasting responses of land and ocean (Ruddiman 2001, Ritter 2006).

Models of simulation of Pangean climates during the pre-rift phase (Kutzbach 1994) indicated a strong reversal between summer and winter monsoon circulations. According to Scherer and Goldberg (2007), the Gondwana monsoons became milder from the Early Jurassic onwards, terminating at the latest Jurassic or earliest Cretaceous. Nevertheless, because of its huge size, climate model simulates widespread dry continental climate in the Pangean interior, in the absence of the moderating influence of oceanic moisture (Ruddiman 2001).

Taking into account the palaeogeographic data, the models of climate simulation for the Pangea during the Early Cretaceous, and the modern climate system established by Köppen (1936), the tropical wet and dry or savanna climate could be better inferred for the time of deposition of the Missão Velha Formation. This yearround warm tropical climate is defined by pluviometer and temperature regimes, with a very long dry season (winter) and a wetter, rainy season (summer). Like the monsoon climate, tropical wet and dry or savanna climate has a distinct seasonality to its precipitation. Still, this wet season is much shorter and receives far less precipitation than the monsoon climate (Ritter 2006).

The growth patterns characterized by two welldemarcated seasons, as demonstrated by the growth ring structure, are defined in monsoon and savanna climates (Wright 1990).

The presence of fossils of turtles, crocodiles, lizards and amphibians described from sandstone sequences of the Missão Velha Formation (Brito et al. 1994) indicated that the region was not an extreme desert, and fresh water may have been present in at least ephemeral streams and lakes. The streams are likely to have been sourced on the mountainous flanks of the rift valley that was subsequently to become the southern Atlantic Ocean (Spicer 2003).

The combined evidence from fossil floral composition, leaf physiognomy, and sedimentological indicators suggests that this region was characterized by a hot, sub-humid to semi-arid climate typical of present-day savanna region (Willis and McElwain 2002).
The palaeoclimatic parameters evidenced in growth rings of the wood assemblage of Grota Funda outcrop allowed to infer a low latitude summer-wet biome well characterized in the paleoclimatic map from the JurassicCretaceous transitions presented by Rees et al. (2000) (Fig. 6). These dendrological data associated to results obtained in arthropod-plant interaction (Pires and Guerra-Sommer 2009) constrains the stratigraphic level of fossil wood occurrence in the Missão Velha Formation to the interval Early Berriasian, confirming the stratigraphic framework proposed by Arai et al. (2004) and Arai (2006).

\section{CONCLUSIONS}

1) The presence of growth rings as a common character in fossil woods from the Grota Funda outcrop, Missão Velha Formation (Araripe Basin), indicates seasonal variation in tree growing conditions, characterized by cyclical alternation of dry and wet periods;

2) Subtly developed growth rings in fossil woods are interpreted to have formed in response to a seasonal climate, probably due to precipitation restrictions, which led to a soil-water shortage;

3) The Mean Sensitivity coefficient from growth rings in fossil woods is high, indicating unstable palaeoenvironmental conditions;

4) The false growth rings can be produced by the occurrence of droughts during the growing season and/or arthropod damage during the life-cycle of trees;

5) The patterns of growth rings are consistent with a tropical wet and dry or savanna climate;

6) Integration between the present dendrological data and results from arthropod-plant interaction in the studied plant assemblage indicates a southern summer wet biome developed during the Early Cretaceous throughout a greenhouse climate phase.

\section{ACKNOWLEDGMENTS}

We acknowledge the contribution of Dr. Narendra K. Srivastava from Universidade Federal do Ceará, for field support and to Dr. Ismar Carvalho (Universidade Federal do Rio de Janeiro) for loan of some specimens. 


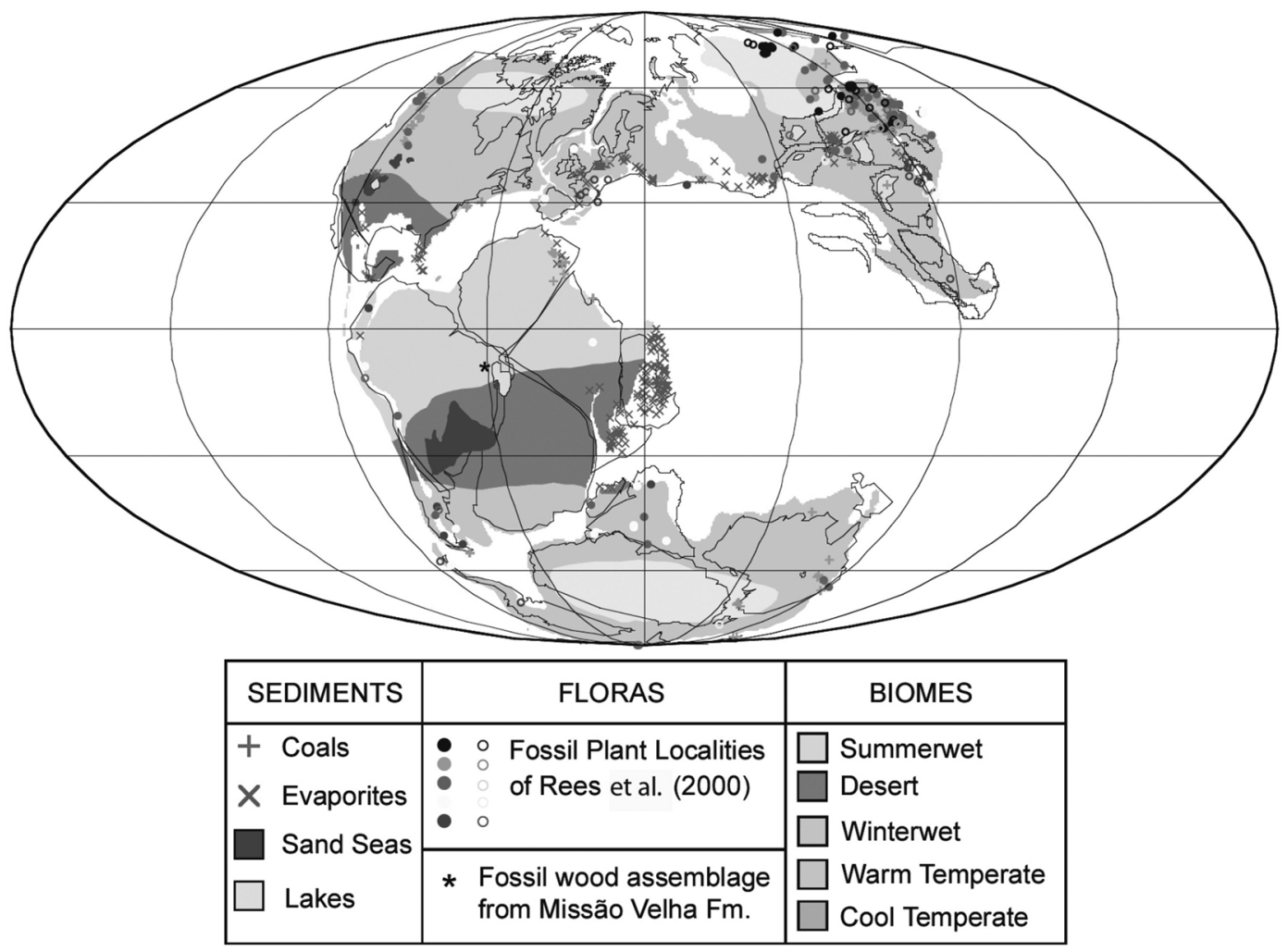

Fig. 6 - Paleoclimate map from the Jurassic-Cretaceous transition with the localization of fossil wood assemblage of the Missão Velha Formation (modified from Rees et al. 2000).

The research was financed from research projects, grants and doctorate scholarship from Conselho Nacional de Desenvolvimento Científico e Tecnológico (CNPQ).

\section{RESUMO}

A partir de análise de anéis de crescimento em lenhos de coníferas silicificadas provenientes da Formação Missão Velha (Bacia do Araripe - Brasil), obteve-se importantes informações a respeito da periodicidade de produção lenhosa durante o início do Cretáceo, na região do equador. Apesar das estimativas de temperatura apresentarem-se elevadas, os dados dendrológicos indicam que o clima foi caracterizado pela alternância cíclica de períodos secos e chuvosos, influenciado por precipitações periódicas, típico das condições atuais de clima tropical úmido e seco ou savana. A abundância de falsos anéis de crescimento pode ser atribuída tanto a secas ocasionais quanto a danos causados por artrópodes. Os dados paleoclimáticos aqui obtidos corroboram com modelos paleoclimáticos que inferem a ocorrência de um bioma de verões úmidos para o limite Neojurássico/Eocretáceo ao sul do equador.
Palavras-chave: Bacia do Araripe - Brasil, dendroclimatologia, fase Pré-Rifte, lenhos silicificados.

\section{REFERENCES}

ARAI M. 2006. Revisão estratigráfica do Cretáceo Inferior das Bacias Interiores do Nordeste do Brasil. Geociências 25: $7-15$.

Arai M, Carvalho IS And Cassab RCT. 2004. Bacias sedimentares brasileiras. Phoenix 72: 10-17.

Assine ML. 1992. Análise estratigráfica da Bacia do Araripe, nordeste do Brasil. Rev Bras Geo 22: 289-300.

AXELROD DI. 1984. An interpretation of Cretaceous and Tertiary biota in polar regions. Palaeogeog Palaeoclimatol Palaeoecol 45: 105-147.

BARRon EJ AND WAShington WM. 1982. Cretaceous climate: a comparison of atmospheric simulations with the geologic record. Palaeogeog Palaeoclimato Palaeoecol 40: 103-133.

Beurlen K. 1962. A geologia da Chapada do Araripe. An Acad Bras Cienc 34: 365-370. 
BRAUN OPG. 1966. Estratigrafia dos sedimentos da parte inferior da Região Nordeste do Brasil (bacias do TucanoJatobá, Mirandiba e Araripe). Rio de Janeiro: DNPM/ DGM, $236 \mathrm{p}$.

Brea M. 1998. Análisis de los anillos de crecimiento en leños fósiles de coníferas de la Formación La Meseta, Isla Seymur (Marambio) Antártida. Paleógeno de América de Sur y de la Península Antártida, Asoci Paleont Argen Pub Esp 5: 163-176.

Brison AL, Philippe M and Thévenard F. 2001. Are Mesozoic wood growth rings climate-induced? Paleobiol 27: $531-538$.

Brito PM, Bertini RJ, Martill DM and Salles LO. 1994. Vertebrate fauna from Missão Velha Formation (Lower Cretaceous, NE Brazil). III Simpósio sobre o Cretáceo do Brasil, Rio Claro, Boletim de Resumos, p. 139-140.

Chaloner WG and McElwain JC. 1997. The fossil plant record and global climatic change. Rev Palaeobot Palynol 95: 73-82.

Chumakov NM. 1995. Climatic zones in the middle of the Cretaceous Period. Strati Geolog Correlat 3: 3-14.

Coimbra JC, Arai M and Carreño AL. 2002. Biostratigraphy of Lower Cretaceous microfossils from the Araripe Basin, northeastern Brazil. Geobios 35: 687-698.

CREBER GT. 1977. Tree rings: a natural data-storage system. Biol Rev 52: 349-383.

Creber GT and Chaloner WG. 1984. Influence of environmental factors on the wood structure of living and fossil trees. Bot Rev 4: 357-448.

Da Rosa AAS And Garcia AJV. 2000. Palaeobiogeographic aspects of northeast Brazilian basins during the Berriasian before the break up of Gondwana. Cret Res 21: 221-239.

Douglass AE. 1928. Climatic cycles and tree growth. v. 2: A study of the annual rings in trees in relation to climate and solar activity. Carn Instit Wash Public 289: 1-127.

Drinnan AN AND Chambers TC. 1986. Flora of the Lower Cretaceous Koonwarra Fossil Bed (Kurumburra Group), South Gippsland, Victoria. In: JELL PA AND Roberts J (Eds), Plants and Invertebrates from the Lower Cretaceous Koonwarra Fossil Bed, South Gippsland, Victoria, p. 1-77.

FALCON-LANG HJ. 2000a. A method to distinguish between woods produced by evergreen and deciduous coniferopsids on the basis of growth ring anatomy: a new palaeoecological tool. Palaeont 43: 785-793.
FALCON-LANG HJ. 2000b. The relationship between leaf longevity and growth ring markedness in modern conifer woods and its implications for palaeoclimatic studies. Palaeogeog Palaeoclimatol Palaeoecol 160: 317-328.

FALCON-LANG HJ. 2005. Global climate analysis of growth rings in woods, and its implications for deep-time paleoclimate studies. Paleobiol 31: 434-444.

FAlCON-LANG HJ AND CANTRILl DJ. 2000. Cretaceous (Late Albian) coniferales of Alexander Island, Antarctica. 1: wood taxonomy: a quantitative approach. Rev Palaeobot Palynol 111: 1-17.

FISCHER AG. 1984. Biological innovations and the sedimentary record. In: Holland H AND TRENDAL AF (Eds), Patterns of change in Earth evolution. Berlin: SpringerVerlag, p. 145-157.

Frakes LA, Francis JE AND SyKtus JI. 1992. Climate modes of the Phanerozoic: the history of the Earth's climate over the past 600 million years. Cambridge: Cambridge University Press.

FrancIs JE. 1984. The seasonal environment of the Purbeck (Upper Jurassic) fossil forests. Palaeogeog Palaeoclimatol Palaeoecol 48: 285-307.

FRANCIS JE AND POOLE I. 2002. Cretaceous and early Tertiary climates of Antarctica: evidence from fossil wood. Palaeogeog Palaeoclimatol Palaeoecol 182: 47-64.

FRITTS HC. 1976. Tree rings and climate. San Franscisco: Academic Press.

GÉrards T, YANS J AND GERRIENNE P. 2007. Quelques implications paléoclimatiques de l'observation de bois fossiles du Wealdien Du bassim de Mons (Belgique) Résultats préliminaires. Carnets de Géologie, Mémoire, p. $29-34$.

HORNE DJ. 1995. A revised ostracod biostratigraphy for the Purbeck-Wealden of England. Cretac Res 16: 639-663.

IAWA CommitTeE. 1989. International Association of Wood Anatomists. List of microscopic features for hardwood identification. IAWA Bul 10: 220-332.

JARZEMBOWSKY EA. 1990. A boring beetle from the Wealden of the Weald. In: Boucout AJ (Ed), Evolutionary Paleobiology of Behavior and Coevolution. Amsterdam: Elsevier, p. 273-376.

JEFFERSON T. 1982. Fossil forest from the Lower Cretaceous of Alexander Island, Antarctica. Palaeont 5: 681-708.

KAY PA. 1978. Dendroecology in Canada's forest-tundra transition zone. Arct Alp Res 10: 133-138.

Keller AM AND Hendrix MS. 1997. Paleoclimatologic analysis of a Late Jurassic petrified forest, Southeastern Mongolia. Palaios 12: 282-291. 
KÖPPEN W. 1936. Das geographishe system der Klimate. In: Köppen W AND GEIGER H (Eds), Handbuch der Klimatologie, Band I, Teil C. Berlin: Gebrüder Bomtrager, $44 \mathrm{p}$.

KutzBACH JE. 1994. Idealized Pangean Climates: Sensivity to Orbital Change. Geol Soc Amer Spec Pap 288: 41-55.

PARRISH JT AND SPICER RA. 1988. Middle Cretaceous wood from Nanushuk Group, central North Slope, Alaska. Palaeont 31: 19-34.

Pinto ID AND SANGUinetTi YY. 1958a. O genótipo de Darwinula Brady \& Robertson, 1985. Instituto de Ciências Naturais, Universidade Federal do Rio Grande do Sul, Brasil, Boletim.

Pinto ID And SAnguinetti YY. 1958b. Bisulcocypris, a new Mesozoic genus and preliminary note about its relation with Metacypris and allied forms. Bol Soc Bras Geo 7: 75-90.

Pires EF ANd Guerra-Sommer M. 2009. Plant-arthropod interaction in the Early Cretaceous (Berriasian) of the Araripe Basin (Brasil). Jour S Amer E Scien 27: 50-59.

Pires EF, Guerra-Sommer M AND Scherer CMS. 2005. Late Triassic climate in southernmost Paraná Basin (Brazil): evidence from dendrochronological data. Jour S Amer E Scien 18: 213-221.

Ponte FC. 1972. Análise comparativa da palaeogeologia dos litorais Atlânticos, Brasileiro e Africano. Relatório CPEG-4, PETROBRAS, $20 \mathrm{p}$.

Rees PM, Ziegler AM And VAldes PJ. 2000. Jurassic phytogeography and climates: new data and model comparisons. In: HUBER BT ET AL. (Eds), Warm climates in earth history, Cambridge: Cambridge University Press, p. $297-318$.

RITTER ME. 2006. The Physical Environment: an Introduction to Physical Geography. <http://www.uwsp.edu/geo/ faculty/ritter/geog101/textbook/title_page.html>.

RudDiman W. 2001. Earth's Climate: Past and Future. W.H. New York: Freeman and Company.
Scherer CMS AND Goldberg K. 2007. Palaeowind patterns during the latest Jurassic - Earliest Cretaceous in Gondwana: evidence from Aeolian cross-strata of the Botucatu Formation, Brazil. Palaeogeog Palaeoclimatol Palaeoecol 250: 89-100.

SCOTESE CR. 2003. PALAEOMAP, Earth History, Jurassic. [www document]. URL <http://www.scotese.com>.

SPICER B. 2003. Changing climate and biota. In: Skelton P (Ed), The Cretaceous World. Cambridge: Cambridge University Press, p. 85-162.

SPICER R AND PARRISH JT. 1990. Latest Cretaceous woods of the central North Slope, Alaska. Palaeont 33: 225-242.

TAJIKA E. 1999. Carbon cycle and climate change during the Cretaceous inferred from a biogeochemical carbon cycle model. The Isl Arc 8: 293-303.

VAldes PJ AND SEllwood BW. 1993. A paleoclimate model for Kimmeridgian. Palaeogeog Palaeoclimatol Palaeoecol 95: 47-72.

WALTER H. 1985. Vegetation of the earth and ecological systems of the geo-biosphere. New York: Springer-Verlag.

Wheeler EA AND Lehman TM. 2005. Upper Cretaceous - Paleocene conifer woods from Big Bend National Park, Texas. Palaeogeog Palaeoclimatol Palaeoecol 226: 233-258.

Willis KJ AND MCELWAin JC. 2002. The evolution of plants. Oxford: Oxford University Press.

WRIGHT VP. 1990. Equatorial aridity and climatic oscillations during the Early Carboniferous southern Britain. Jour Geol Soc 147: 359-363.

ZIEGLER AM. 1990. Phytogeographic patterns and continental configurations during the Permian Period. In: McKerrow WS And Scotese CR (Eds), Paleozoic palaeogeography and biogeography. London, Geol Soc London 12: 363-379.

Ziegler AM, Eshel G, Rees PM, Rothfus TA, RowLEY DB AND Sunderlin D. 2003. Tracing the tropics across land and sea: Permian to Present. Let 36: 227-254. 